\title{
CONFIRMATORY FACTOR ANALYSIS OF NERIS TYPE EXPLORER® SCALE - A TOOL FOR PERSONALITY ASSESSMENT
}

\author{
Kirti Makwana \\ Assistant Professor, Charotar University of Science and Technology (CHARUSAT), \\ Changa, Gujarat, India

\section{Dr. Govind B Dave} \\ Dean, Faculty of Management Studies (FMS), \\ Principal, Indukaka Ipcowala Institute of Management (I IM), \\ Charotar University of Science and Technology (CHARUSAT), \\ Changa, Gujarat, India
}

\begin{abstract}
The research explored the validity and reliability of the NERIS Type Explorer ${ }^{\circledR}$ Scale. A total of 1067 management students comprising from fifteen cities of the Gujarat state of India participated, selected by using a probability-based cluster sampling method. A survey design was employed to generate the personality profile of management students of Gujarat. Quantitative data were analysed using Confirmatory Factor Analysis (CFA) using SPSS 23 and AMOS 18. The CFA approach verified the NERIS Type Explorer ${ }^{\circledR}$ Scale of personality assessment was satisfactory in the context of management students from Gujarat. This positive empirical evidence supports the greater importance of validating and confirming the scale of personality assessment relative to generate personality profiles.
\end{abstract}

Key words: Confirmatory Factor Analysis (CFA), Personality Assessment, NERIS Type Explorer ${ }^{\circledR}$ Scale.

Cite this Article: Kirti Makwana and Govind B Dave, Confirmatory Factor Analysis of NERIS Type Explorer ${ }^{\circledR}$ Scale - A Tool For Personality Assessment, International Journal of Management, 11(9), 2020, pp. 257-265.

http://iaeme.com/Home/issue/IJM?Volume=11\&Issue=9

\section{INTRODUCTION}

The history of the progress of various personality assessment tools and their inferences for reliability, validity, and measurements is as interesting as the history of personality assessment. Earlier days, the assessment tools were simpler, which derived stable personality traits which are observable indicators, such as the structure of a body, physical appearance, or 
scull size. However, with the introduction of "psychoanalysis" the scholars in the field of psychology attempted to go beyond the visible indicators. They explored the unconscious motives and personality patterns. Though provided that interesting insights, these efforts were every so often struggling with a low degree of consistency. Hence the scholars were quested for the validity, reliability, consistency, and thus the usability.

In the early twentieth century in France, the modern psychological tests and assessment originated. Alfred Binet and a colleague in 1905 developed an assessment tool to help to allocate school children in their suitable sections. In a short span of ten years, the English version of the assessment tool was used in the United States. Further in 1917, when the US and Germany entered in World War I, psychological assessment tools provided a methodology to screen large numbers of military recruits. During World War II, psychological assessment tools were more preferred for military recruitment. Following the war, progressively more assessment tools admitting to quantify a range of psychological variables were developed and appiled. The modern assessment tools measure not only intellect but also personality, facets of functioning of a brain, performance at workplace, and many other psychological and social functioning aspects. The world's receptiveness to Alfred Binet's assessment procreated not only more assessment tools but more test creators (scholars and researchers), editors, and users.

\section{OBJECTIVE}

The objective of this research article is:

- to expand the Confirmatory Factor Analysis (CFA) to the personality assessment tool, NERIS Type Explorer ${ }^{\circledR}$ scale for a comprehensive construct validation framework.

\section{LITERATURE REVIEW}

Krech and Crutchfield (1969) explained that "The research of personality theory is the most interesting mysteries and a tough challenge of psychology". A hindrance for measuring a personality is lack of agreement related to the definition of personality. Super (1949) mentioned that the field of personality is one of the most prevalent, thought-provoking, significant, and confused in modern psychology. Considering this, Lindzey (1964) defined personality as "Personality comprises a set of standards or expressive terms which are used to define the one being studied as per the variables or dimensions that occupy a essential position in the specific concept applied".

Allport (1956) has claimed that no universal laws for a common person's reaction to any circumstances could perpetually drive to an acceptable insigts of personality. His fundamental idea is the distinctiveness of an individual. As per his viewpoint, "Personality is the active organisation within one and psychophysical systems derives one's exclusive adjustment to his surrounding". This description is all-inclusive, extensive, and purposeful. It provides complete deliberation to the personality of an individual.

Personality is an elusive construct, which is frequently used to describe behavioral consistency in individuals and behavioral individuality among people. Psychology literature has many definitions with some centering on explicit characteristics of people. (Goldstein, 1963) whereas others understand the one within the framework of the social order or specific social background (Sullivan, 1953). Traditionally personality assessment is concentrating on the measuring the extent of personal reactions, attitudes, and personality styles and/or motivational traits compared to intellectual capabilities such as brainpower or accomplishment. In reflection of the past research concerning the concept of personality and assessment of personality, a modern definition is offered by Cohen \& Swerdlik (2005) as 
"one's distinct collection of psychological individualities and states". They outlined personality assessment as "the measurement and assessment of psychological traits, states, values, interests, attitudes, worldview, acculturation, identity, sense of humour, reasoning, behaviour styles, and/or related physiognomies".

\section{NERIS TYPE EXPLORER ${ }^{\circledR}$ SCALE}

NERIS Type Explorer ${ }^{\circledR}$ Scale is a free personality assessment tool. It is mainly constructed on the Myers and Briggs theories, though the aforementioned introduced new term in the four personality preferences and added one more preference which signifies an individual's response to coping with the stress. Since the NERIS Type Explorer ${ }^{B}$ Scale framework has been rather reinvented, the present study tries to explore what extent then personality type outcomes are consistent with the results generated using MBTI ${ }^{\circledR}$ or other personality assessment tools.

This personality test emphasizes five personality facets: Mind, Energy, Nature, Tactics, and Identity. Collectively they contain the sixteen personalities of the NERIS Type Explorer ${ }^{B}$ Scale. These sixteen personality types were derived from the theories and philosophies of Carl Jung and Katharine Briggs and Isabel Briggs Meyers. Through a series of questions (60 statements included in the scale), this tool provides an individual's personality traits, preferences and generates a unique personality profile. The results generate five personality facets that are recognized with a letter, which are combined to create a unique personality type.

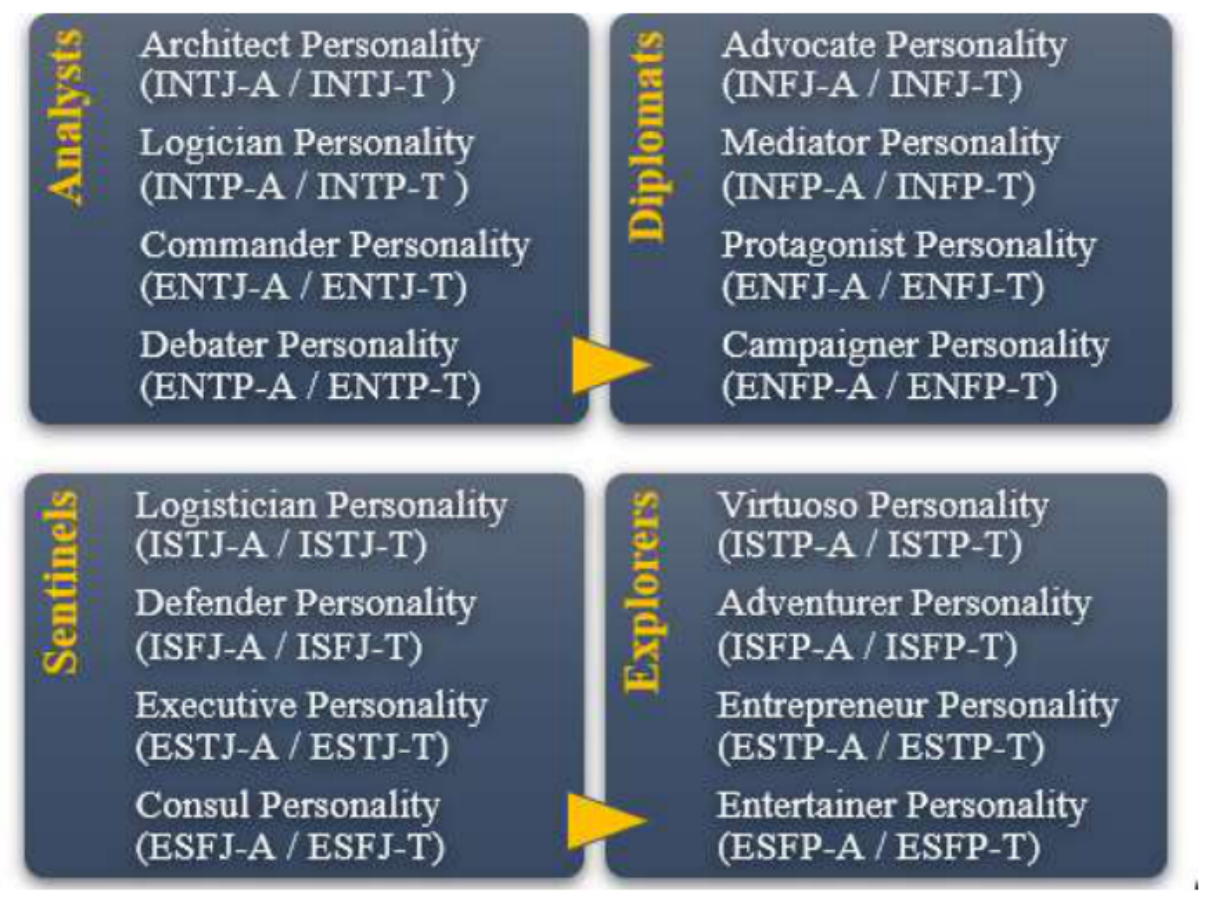

Figure 1 Sixteen Personality Types 
Confirmatory Factor Analysis of NERIS Type Explorer ${ }^{\circledR}$ Scale - A Tool For Personality Assessment

\begin{tabular}{|l|} 
- Introverted prefers unsocial happenings and get exhausted by social interactions. \\
Quite sensitive to external stimulation. \\
- Extraverted prefers group events and get thrilled by social interactions. More \\
enthusiastic and get easily excited. \\
\hline Energy (How one see the world and processes information) \\
- ObServant are extremely practical, realistic and down-to-earth. Have strong \\
traditions and emphasis on what is happening or has previously happened. \\
- INtuitive people are creative, unprejudiced and inquisitive. Prefer innovation over \\
steadiness and emphasis on secreted meanings and future opportunities.
\end{tabular}

\begin{tabular}{|l|}
\hline Thinking people are more objective and rational, prefer logic over emotions. Hide \\
feelings and perceive efficiency as more imperative than cooperation. \\
- Feeling people are sensitive and expressive. More empathic and less competitive. \\
Focus on social congruence and collaboration. \\
- Judging people are conclusive, thorough and highly planned. Value clarity, \\
predictability and conclusion, favouring structure and planning to impulsiveness \\
- Prospecting persons are good at extemporizing and perceiving prospects. \\
Flexible, calm, nonconformists and prefer to keep options open. \\
Tactics (One's approach to work, plan and making decisions) \\
- Assertive people are self-confident, calm and resilient to stress. Refuse to worry \\
much and don't push themselves too hard when it comes to accomplishing goals. \\
- Turbulent people are self-conscious and sensitive to stress. Experience a wide \\
range of sentiments and to be success-driven, perfectionistic and keen to improve.
\end{tabular}

Figure 2 Five Personality Facets of The NERIS Type Explorer ${ }^{\circledR}$ Scale

\section{RESEARCH DESIGN AND METHODOLOGY}

The research study is based on primary data, resulting in a descriptive method of research using a pretested structured scale i. e NERIS Type Explorer ${ }^{\circledR}$ Scale. The purposive sampling method was used for data collection. 1067 management students from thirty (30) AICTE approved B- Schools from fifteen (15) cities of Gujarat state were taken into consideration for the research. Selected cities were Anand, Vallabh Vidyanagar, Nadiad, Rajkot, Surat, Bardoli, Vadodara, Ahmedabad, Wadhwan, Gandhinagar, Kherva, Patan, Bhavnagar, and Bhuj, which represents North, South, East, West and Middle part of the state.

\section{RESULTS}

The term "reliability" in the psychological measurement context, means accurateness, consistency, and stability of scores attained on a measurement tool. This reliability signifies a quantitative measurement of the extent to which the instrument gives consistent and/or stable outcomes. A Cronbach's alpha is a coefficient that measures if the questions fit into the same scale produce alike scores. The values of alpha are generally expected to be the range of 0.70 to 0.90. A lower value of Cronbach's alpha (i.e. values than 0.70) is a suggestion that the questions being evaluated might not measure an alike construct. Higher values of Cronbach's alpha (i.e. more than 0.90) recommends redundancy. Alpha values of the scale are between 
0.70 and 0.90, which approves that the NERIS Type Explorer ${ }^{\circledR}$ Scale is consistent and measuring all its scales well. Internal consistency approximates of reliability specifies the homogeneousness of statements that include the assessement tool or scale. Preferably, the distinct statements in the assessement tool are corelated moderate to high level amid themselves thus giving support to the concept that the statements in the assessment tool are to be expected to tap the identical fundamental psychological construct or have an identical purpose.

Confirmatory Factor Analysis (CFA) is a multivariate statistical method. It scrutinize how sound the quantity of constructs are specified by the measured varibales. One can find the quantity of factors essential in the data and which measured variable is associated with the latent variable. CFA is a statistical method used to check or reject the measurement theory. CFA is considered as theoretically significant and ought to be extensively applied, as it suggests hypothesis testing for factor analytic problems.

Table 1 CMIN/DF $(\mathrm{N}=1067)$

\begin{tabular}{|l|c|c|c|c|c|}
\hline \multicolumn{1}{|c|}{ Model } & NPAR & CMIN & DF & P & CMIIN/DF \\
\hline Default & 190 & 4695.67 & 1700 & 0.000 & 2.76 \\
\hline Saturated & 1890 & 0.000 & 0 & \multicolumn{1}{|c|}{} \\
\hline Independence & 60 & 8328.88 & 1830 & 0.000 & 4.55 \\
\hline
\end{tabular}

Table 2 RMSEA $(\mathrm{N}=1067)$

\begin{tabular}{|l|c|c|c|c|}
\hline \multicolumn{1}{|c|}{ Model } & RMSEA & LO 90 & HI 90 & PCLOSE \\
\hline Default & 0.032 & 0.031 & 0.034 & 1.00 \\
\hline Independence & 0.046 & 0.045 & 0.047 & 1.00 \\
\hline
\end{tabular}

Confirmatory Factor Analysis (CFA) was applied to validate NERIS Type Explorer ${ }^{\circledR}$ Scale. For the NERIS Type Explorer ${ }^{\circledR}$ Scale model evaluated in this, the following statistical values were derived: $\chi 2$ (4695.67, $\mathrm{n}=1067), \mathrm{p}>0.05, \mathrm{RMSEA}=0.032$. The model fit values for Chi-square Mean/Degree of Freedom (CMIN / DF) is 2.76 (as revealed in table 1) and the Root Mean Square Error of Approximation (RMSEA) is 0.032 (as shown in table 2), these values recommend that the constructs used in the research are validated. This study use response data from personality questionnaire survey administrations and explore the latent factor structure by CFA. CFA measures are appropriate when tests for certain relational hypotheses are to be tested.

Table 3 Confirmatory Factor Analysis of NERIS Type Explorer ${ }^{\circledR}$ Scale $(\mathrm{N}=1067)$

\begin{tabular}{|c|c|c|c|c|c|c|}
\hline ن் & 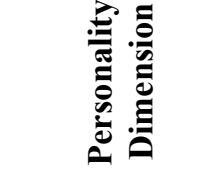 & Statement & 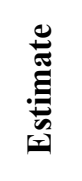 & is & نُ & a \\
\hline S1 & \multirow{9}{*}{$\begin{array}{l}\text { Extraversion } \\
\text { (E)/ } \\
\text { Introversion } \\
\text { (I) }[1]\end{array}$} & Struggle to acquaint with to others & 1.00 & & & \\
\hline $\mathrm{S} 2$ & & Frequently get so lost in thoughts & 1.01 & 0.26 & 3.89 & $*$ \\
\hline S3 & & Responding to e-mails immediately & 1.53 & 0.35 & 4.36 & * \\
\hline S5 & & Not initiating conversations & 1.06 & 0.27 & 3.89 & * \\
\hline S6 & & Rarely doing something out of curiosity & 1.13 & 0.27 & 4.06 & * \\
\hline S7 & & Feeling superior to others & 0.95 & 0.25 & 3.67 & $*$ \\
\hline S9 & & Motivated and energetic & 1.80 & 0.38 & 4.63 & * \\
\hline S13 & & Love to be a centre of attention & 1.37 & 0.31 & 4.34 & * \\
\hline S23 & & Prefere an interesting book / a video game over a social & 1.40 & 0.33 & 4.16 & * \\
\hline
\end{tabular}


Confirmatory Factor Analysis of NERIS Type Explorer ${ }^{\circledR}$ Scale - A Tool For Personality Assessment

\begin{tabular}{|c|c|c|c|c|c|c|}
\hline نَّ & 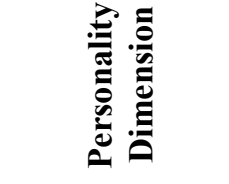 & Statement & 莺 & $\dot{\varphi g}$ & نُّ & A \\
\hline & \multirow{19}{*}{$\begin{array}{l}\text { Observant } \\
\text { (S)/ Intuition } \\
(\mathrm{N})[2]\end{array}$} & event & & & & \\
\hline S31 & & Easily get involved in social activities & 2.15 & 0.45 & 4.75 & * \\
\hline S34 & & Enjoy going to social events & 1.49 & 0.34 & 4.39 & $*$ \\
\hline S37 & & Relatively reserved and quiet & 1.22 & 0.30 & 4.07 & * \\
\hline S39 & & Anticipate the reasons for human survival & 1.48 & 0.33 & 4.48 & * \\
\hline S47 & & Feeling energetic with people & 1.94 & 0.41 & 4.68 & * \\
\hline S55 & & Prefer to avoid the centre & 0.94 & 0.26 & 3.61 & $*$ \\
\hline S59 & & Interested in unusual | uncertain things & 1.78 & 0.38 & 4.62 & * \\
\hline S60 & & Initiate in social situations & 2.05 & 0.43 & 4.68 & * \\
\hline S4 & & Stays relaxed in a pressurized situation & 1.00 & & & \\
\hline S14 & & Practical than Creative & 1.32 & 0.25 & 5.23 & * \\
\hline S15 & & Persons can hardly upset & 0.83 & 0.21 & 3.96 & * \\
\hline S25 & & Hardly getting carried away by imaginations & 1.25 & 0.24 & 5.21 & * \\
\hline S26 & & Lost in thoughts while walking in nature & 1.59 & 0.29 & 5.45 & $*$ \\
\hline $\mathrm{S} 30$ & & Dreams focus on the actual world and events & 1.27 & 0.24 & 5.17 & $*$ \\
\hline S35 & & $\begin{array}{l}\text { Spending time in discovering impracticable and } \\
\text { unrealistic ideas }\end{array}$ & 1.37 & 0.26 & 5.30 & * \\
\hline S50 & & Mind busy with unexplored thoughts | strategies & 1.70 & 0.29 & 5.68 & $*$ \\
\hline S51 & & Not calling yourself a dreamer & 0.47 & 0.18 & 2.54 & $\begin{array}{c}0.0 \\
1\end{array}$ \\
\hline S53 & & Relying on experience than imagination & 1.43 & 0.26 & 5.45 & $*$ \\
\hline S10 & \multirow{15}{*}{$\begin{array}{l}\text { Thinking (T) / } \\
\text { Feeling (F)[3] }\end{array}$} & $\begin{array}{l}\text { Winning a debate matters less than not making anyone } \\
\text { upset }\end{array}$ & 1.00 & & & \\
\hline S11 & & Urge to justify yourself to other people & 1.19 & 0.18 & 6.40 & * \\
\hline S17 & & Difficult to relate to other's feelings & 0.65 & 0.15 & 4.32 & $*$ \\
\hline S18 & & A quick change in moods & 1.12 & 0.18 & 6.03 & $*$ \\
\hline S19 & & Truth is important than sensitivities & 1.24 & 0.19 & 6.57 & $*$ \\
\hline S20 & & Do't worry about how actions affect others & 0.91 & 0.17 & 5.30 & * \\
\hline S28 & & Preferring to see a child grow up a kind than smart & 1.03 & 0.17 & 5.96 & $*$ \\
\hline S29 & & Don't let others influence actions & 0.98 & 0.16 & 6.04 & * \\
\hline S33 & & Emotions control you more than you controlling them & 1.14 & 0.18 & 6.12 & * \\
\hline S38 & & Difficult to fire devoted but underachieving workers & 0.91 & 0.15 & 5.79 & * \\
\hline $\mathrm{S} 40$ & & Logic is generally more central than the heart & 1.31 & 0.19 & 6.69 & $*$ \\
\hline S42 & & $\begin{array}{l}\text { Offer emotive care than advising ways to deal with the } \\
\text { problem }\end{array}$ & 1.25 & 0.19 & 6.35 & * \\
\hline S45 & & Being right is significant than being supportive & 1.17 & 0.18 & 6.30 & $*$ \\
\hline S46 & & $\begin{array}{l}\text { Everyone's opinions are to be respected irrespective of } \\
\text { if they are reinforced by facts or not }\end{array}$ & 1.16 & 0.18 & 6.43 & * \\
\hline S58 & & Believe in pleasing others than to be powerful & 1.23 & 0.18 & 6.58 & * \\
\hline S56 & \multirow{10}{*}{$\begin{array}{l}\text { Judging }(\mathrm{J}) / \\
\text { Prospecting } \\
\text { (P)[4] }\end{array}$} & Being organized is important than being flexible & 1.00 & & & \\
\hline S48 & & Keeping the work environment quiet and tidy & 0.89 & 0.16 & 5.59 & $*$ \\
\hline S44 & & Well thought out travel plans & 0.87 & 0.15 & 5.73 & $*$ \\
\hline S41 & & $\begin{array}{l}\text { More random energy spikes than a systematic and } \\
\text { planned approach }\end{array}$ & 1.20 & 0.16 & 7.23 & * \\
\hline S36 & & Developing a plan and sticking to it & 0.98 & 0.14 & 6.76 & $*$ \\
\hline S32 & & Natural improviser than a cautious organizer & 1.14 & 0.16 & 7.17 & $*$ \\
\hline S24 & & $\begin{array}{l}\text { Prefer to improvise than spending time to come up with } \\
\text { a detailed plan }\end{array}$ & 1.41 & 0.18 & 7.78 & * \\
\hline S21 & & Keep options open than having a to-do list & 0.90 & 0.14 & 6.43 & $*$ \\
\hline S16 & & $\begin{array}{l}\text { No problems to come up with a schedule and sticking } \\
\text { to it }\end{array}$ & 0.88 & 0.15 & 5.79 & * \\
\hline S12 & & Normally misplace things & 0.99 & 0.16 & 6.17 & * \\
\hline
\end{tabular}




\begin{tabular}{|c|c|c|c|c|c|c|}
\hline نّ & 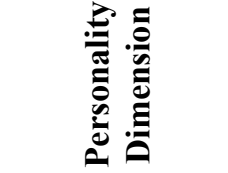 & Statement & 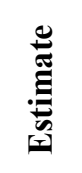 & $\dot{\varphi s}$ & نُ & $a$ \\
\hline S8 & & Procrastinate until get enough time to complete & 1.07 & 0.16 & 6.70 & $*$ \\
\hline S22 & \multirow{7}{*}{$\begin{array}{l}\text { Assertive (A) / } \\
\text { Turbulent (T) } \\
{[5]}\end{array}$} & Envious of others & 1.00 & & & \\
\hline S27 & & Restless & 1.26 & 0.18 & 6.75 & $*$ \\
\hline S43 & & Rarely feel insecure & 0.74 & 0.14 & 5.15 & * \\
\hline S49 & & Emotionally stable & 0.54 & 0.13 & 4.13 & * \\
\hline S52 & & Hard to relax while speaking in front of many & 1.16 & 0.18 & 6.45 & * \\
\hline S54 & & Worrying much about what other people think & 1.54 & 0.21 & 7.24 & $*$ \\
\hline S57 & & Feel anxious in stressful situations & 1.39 & 0.19 & 7.24 & $*$ \\
\hline
\end{tabular}

\section{KEYNOTES}

1. The attitude of an individual in terms of Extraversion (E) - Introversion (I), i.e. an individual's preference of outward or inward turning.

2. Perceiving of an individual in terms of Observant (S) - Intuition (N), i.e. ability of an individual for data collecting and behavior of individuals like paying more attention to information or patterns and possibilities when they receive the information.

3. Decision-making preferences in terms of Thinking (T) -Feeling (F), i.e. giving preference to logic and consistency over people and special circumstances.

4. Lifestyle Preferences of an individual in terms of Judging $(\mathrm{J})$ - Prospecting $(\mathrm{P})$, i.e. how an individual like to oriented to the outer world, behaviors others have a habit of to see and preference of a more organized and decided style of living (Judging) or a more adjustable and flexible lifestyle (Perceiving).

5. Assertive ( $\underline{\mathrm{A}})$ people are self-assured, even-tempered, and reluctant to stress. They worry less and do not push too hard to achieving goals. Turbulent $(\mathrm{T})$ people are self-conscious and responsive to stress.

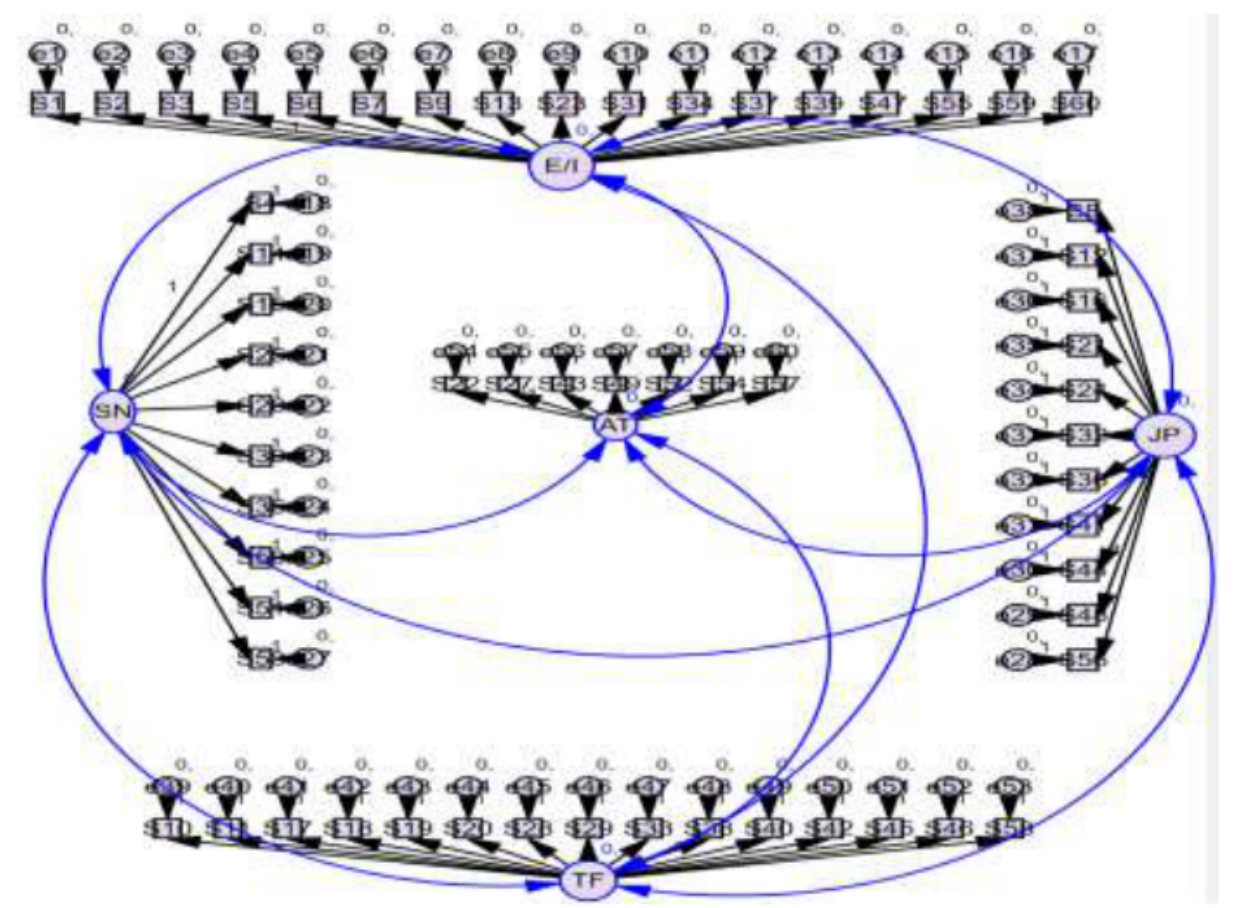

Figure 3 Confirmatory Factor Analysis of NERIS Type Explorer ${ }^{\circledR}$ Scale

Note: Detailed statements related to S1 - S6 can be referred in Table - 3 . 
$\mathrm{P}$ values for standardized coefficients are less than 0.05 for all the observed variables (as shown in table 3). Hence, for the NERIS Type Explorer ${ }^{\circledR}$ Scale there is no need to drop any of the variables from any construct. So, the model which was part of the study (NERIS Type Explorer ${ }^{\circledR}$ Scale) is perfectly validated. Confirmatory Factor Analysis of the NERIS Type Explorer ${ }^{\mathbb{B}}$ Scale model fit generated on AMOS is shown in figure 3.

\section{CONCLUSION}

This research was intended to examine the psychometric properties of the NERIS Type Explorer ${ }^{\circledR}$ Scale. The research used a multiple analytic method in representing the multidimensional factorial validity and reliability of the NERIS Type Explorer ${ }^{\circledR}$ Scale. Cronbach's alpha scores which estimates internal consistency and reliability of the scale, were observed to be consistent as well as reliable. Outcomes derived from the current research specify that psychometric properties of the NERIS Type Explorer ${ }^{\circledR}$ Scale are internally consistent and reliable. Results of the Confirmatory Factor Analysis (CFA) model methodology revealed theoretical support for the multidimensional model and it precisely describes the broad construct of personality type. The outcomes of the current research study provide statistical evidence that the NERIS Type Explorer ${ }^{\mathbb{B}}$ Scale is a powerful instrument to measure the personality style of an individual. The results derived in the research are clear evidences which specify that the NERIS Type Explorer ${ }^{\circledR}$ Scale can be assuredly be applied to have a better understanding and generating the personality profile of individuals.

\section{REFERENCES}

[1] Allen, M., and Yen, W. (1979) Introduction to Measurement Theory. Belmont, CA: Wadsworth.

[2] American Educational Research Association (AERA), American Psychological Association (APA), and the National Council on Measurement in Education (NCME). (1999). Standards for educational and psychological testing. Washington, DC: American Psychological Association. Bentlee, P. M. \& Chou, C. (1987). Practical issues in structural modelling. Sociological Methods and Research, 16, 78-117.

[3] Arbuckle, J. \& Woke, W. (1999). Analysis of Moment Structures (AMOS) 4 user's reference guide Chicago: Smallwaters Corporation.

[4] Bollen, K. A. (1989). Structural equations with latent variables. New York: John Wiley \& Sons.

[5] Bryant, F. B., \& Yarnold, P. R. (1995). Principal-components analysis and exploratory and confirmatory factor analysis. In L. G. Grimm \& P. R. Yarnold (Eds.), Reading and understanding multivariate statistics (pp. 99-136). Washington, DC: American Psychological Association.

[6] Byrne, B. M. (2001). Structural equation modeling with AMOS: Basic concepts, applications, and programming. Mahwah, NJ: Erlbaum

[7] Cohen, R. J., and Swerlik, M. E. (2005) Psychological Testing and Assessment, 6th ed. New York, NY: McGraw-Hill.

[8] Cohen, R.J. \& Swerdlik, M.E. (2005) Psychological Testing and Assessment (6th Edition). New York: McGraw Hill

[9] Comrey, A. L., and Lee, H. B. (1992). A First Course in Factor Analysis, 2nd ed. Hillsdale, NJ: Lawrence Erlbaum Associates, Inc.

[10] Cronbach, L. J. (1946). Response sets and test validity. Educational and Psychological Measurement, 6, 474-494. 
[11] Gagne, P. \& Hancock, G. R. (2006). Measurement model quality, sample size, and solution propriety in confirmatory factor models. Multivariate Behavioral Research, 41 (1), 65-83.

[12] Geier, J. G. (1977). The Personal Profile System. Minneapolis, MN: Performax Systems, International.

[13] Gillen, B. (1973). Readability and human interest scores of thirty-four current introductory psychology texts. American Psychologist, $28(11), \quad 1010-$ 1011. https://doi.org/10.1037/h0035637

[14] Goldstcin K: Autobiography, In a History of Psychology in Aulobiography. E G Boring G Linaicy. editors. vol 5, p 160. AppelonCenturyCrofit. New York. 1967.

[15] Guilford, J. P. (1954). Psychometric Methods, 2nd ed. New York, N.Y: McGraw-Hill.

[16] Hu, L. \& Bentler, P. M. (1999). Cutoff criteria for fit indexes in covariance structure analysis: Conventional criteria versus new alternatives. Structural Equation Modeling, 6 (1), 1-55.

[17] Shaffer, J. P., \& Sinnett, E. R. (1964). A factor analysis of Hall and Lindzey's ratings of personality theories. Acta Psychologica, Amsterdam, 22(2), 135144. https://doi.org/10.1016/0001-6918(64)90012-5

[18] Sullivan, H. S. (1953). The interpersonal theory of psychiatry. W W Norton \& Co.

[19] Sun, J. (2005). Assessing goodness of fit in confirmatory factor analysis. Measurement and Evaluation in Counseling and Development, 37, 240-256.

[20] Tannenbaum, A. S., \& Allport, F. H. (1956). Personality structure and group structure: An interpretative study of their relationship through an event-structure hypothesis. The Journal of Abnormal and Social Psychology, 53(3), 272-280. https://doi.org/10.1037/h0040282

[21] Traub, R. E. (1994) Reliability for the Social Sciences. Thousand Oaks, CA: Sage.

[22] Van Prooijen, J. \& Van Der Kloot, W. A. (2001). Confirmatory analysis of exploratively obtained factor structures. Educational and Psychological Measurement, 61, 777-792. 